\title{
TATA CARA DAN PENGELOLAAN WAKAF UANG DI INDONESIA
}

\author{
Junaidi Abdullah \\ Sekolah Tinggi Agama Islam Negeri (STAIN) Kudus \\ e-mail: abdillahrafandra@gmail.com
}

\begin{abstract}
Cash waqf is not refers to money waqf only but also cover waqf of capital stock and obligation. This kind of waqf has been acknowledged by waqf institution in Indonesia and also has been regulated by the government. This article describes its regulation and how to do cash waqf in Indonesia.
\end{abstract}

Keywords: Cash Waqf, Regulation, and Management

\section{Pendahuluan}

Manusia merupakan makhluk yang di ciptkan Allah SWT adalah untuk beribadah Bentuk ibadah yang dilakukan oleh manusia ada yang berdimensi individual dan vertikal (seperti sholat dan puasa) dan ada pula yang berdimensi sosial dan horizontal (seperti zakat, infak, shodaqoh maupun wakaf).

Wakaf sebagai ibadah yang berdimensi sosial dan horizontal tentu sangat penting bagi umat, karena disamping zakat, ibadah wakaf juga bisa meningkatkan kesejahteraan masyarakat dan bisa menghilangkan kemiskinan.

Wakaf yang berarti «menahan» adalah menahan harta yang diambil manfaatnya tanpa musnah seketika, dan 


\section{Junaidi Abdullah}

penggunaannya untuk hal-hal yang diperbolehkan syarā dengan maksud mendapatkan keridlaan dari Allah. Dengan melepaskan harta wakaf itu, secara hukum wakif telah kehilangan hak kepemilikanya sehingga ia tidak lagi memiliki wewenang atau hak untuk menggunakannya untuk kepentingan pribadi dan hak untuk memindahtangankan atau mengalihkan kepemilikannya kepada pihak lain, seperti menjual, menghibahkan termasuk mewariskan kepada ahli waris (M Daud Ali, 1988: 94).

Wakaf merupakan perbuatan hukum wakif untuk memisahkan dan/atau menyerahkan sebagian harta benda miliknya untuk dimanfaatkan selamanya atau untuk jangka waktu tertentu sesuai dengan kepentingannya guna keperluan ibadah dan/atau kesejahteraan umum menurut syariah.(Pasal 1 Angka 1 UU No. 41 Tahun 2004 tentang Wakaf).

Indonesia merupakan negara berpenduduk mayoritas Muslim, namun pemahaman atau pengetahuan keislamannya masih dangkal, karena biasanya memahami wakaf hanya berbentuk tanah atau benda-benda yang tidak bergerak lainnya. Padahal yang namanya wakaf itu bisa berupa benda bergerak maupun benda yang tidak bergerak.

Ruang lingkup wakaf yang selama ini dipahami secara umum cenderung terbatas pada wakaf benda tidak bergerak seperti tanah dan bangunan, maka Undang Undang nomor 41 tahun 2004 tentang Wakaf, memberikan solusi atau aturan bahwa orang yang mewakafkan (wakif) dapat mewakafkan sebagian kekayaannya berupa harta benda wakaf bergerak, baik berwujud atau tidak berwujud yaitu uang, logam mulia, surat berharga, kendaraan, hak kekayaan intelektual, hak sewa, dan benda bergerak lainnya.

Dengan adanya wakaf uang, tentu menjadi efektif dan efisien serta bisa dikembangkan untuk kesejahteraan masyarakat, karena tujuan wakaf tidak hanya diperuntukkan dalam hal ibadah, sosial saja tetapi juga bisa diperuntukkan bagi kesejahteraan masyarakat dan mengentaskan kemiskinan. 
Menurut fatwa MUI tentang Wakaf Uang, yang dinamakan Wakaf Uang (Cash Wakaf/Waqf al-Nuqud) adalah wakaf yang dilakukan seseorang, kelompok orang, lembaga atau badan hukum dalam bentuk uang tunai. Termasuk ke dalam pengertian uang adalah surat-surat berharga.

Dengan adanya Undang-undang Nomor 41 tahun 2004 dan fatwa MUI tentang wakaf uang, maka secara legal formal wakaf uang bisa dilakukan dan dilaksanakan oleh umat Islam di Indoneaia, tentu tata cara dan prosedurnya berbeda dengan wakaf lainnya.

\section{Pembahasan}

\section{Wakaf dan Wakaf Uang \\ Pengertian wakaf}

Wakaf (Ar: waqf $=$ menahan tindakan hukum). Persoalan Wakaf adalah persoalan pemindahan hak milik yang dimanfaatkan untuk kepentingan umum (Ensiklopedi Hukum Islam, 1997: 1905).

Wakaf secara etimologi merupakan bentuk masdar dari kata waqafa-yaqifu yang memiliki makna al habs (menahan) atau al-muks(menetap). Sedangkan wakaf menurut istilah, menahan harta yang dapat dimanfaatkan dengan menjaga pokok harta dan mendistribusikan manfaatnya kepada pihak yang diperbolehkan menerimanya (Siah Khosyi'ah, 2010: 15).

Definisi wakaf menurut mazhab fiqh cukup bervariasi. Kelompok Hanafiyah mengartikan wakaf sebagai menahan materi benda (al-'ain) milik waqif (orang yang mewakafkan) dan menyedekahkan atau mewakafkan manfaatnya kepada siapapun yang diinginkan untuk tujuan kebajikan. Sementara Malikiyah berpendapat, wakaf adalah menjadikan manfaat suatu harta yang dimiliki untuk diberikan kepada orang yang berhak dengan satu akad (sigat) dalam jangka waktu tertentu sesuai dengan keinginan waqif. Adapun dari komunitas mazhab Syafi'iyah mengartikan 


\section{Junaidi Abdullah}

wakaf dengan menahan harta yang bisa memberi manfaat serta kekal materi bendanya (al-'ain) dengan cara memutuskan hak pengelolaan yang dimiliki oleh waqif untuk diserahkan kepada nazir yang dibolehkan oleh syari'ah. Sedangkan Hanabilah mendefinisikan wakaf dengan bahasa yang sederhana, yaitu menahan asal harta (tanah) dan menyedekahkan manfaat yang dihasilkan (Said Agil Husin Al-Munawar, 2004: 127).

Wakaf menurut Peraturan Pemerintah Nomor 28 tahun 1977, Wakaf adalah suatu perbuatan hukum seseorang atau badan hukum yang memisahkan sebagian dari harta kekayaannya yang berupa tanah milik dan melembagakannya untuk selamalamanya untuk kepentingan peribadatan atau kepentingan umum lainnya (Peraturan Pemerintah Nomor 28 Tahun 1977 Tentang Perwakafan Tanah).

Dalam Kompilasi Hukum Islam Indonesia (KHII) disebutkan bahwa wakaf adalah perbuatan hukum seseorang atau kelompok orang atau badan hukum yang memisahkan sebagian dari benda miliknya dan melembagakannya untuk selama-lamanya guna kepentingan umum lainnya sesuai dengan ajaran Islam (Pasal 215 ayat (1) Kompilasi Hukum Islam Indonesia (KHII).

Menurut Undang-undang nomor 41 tahun 2004 tentang Wakaf, yang dimaksud dengan wakaf adalah perbuatan hukum wakif untuk memisahkan dan/atau menyerahkan sebagian harta benda miliknya untuk dimanfaatkan selamanya atau untuk jangka waktu tertentu sesuai dengan kepentingannya guna keperluan ibadah dan/atau kesejahteraan umum menurut syariah.

Dari beberapa pengertian di atas maka dapat disimpulkan yang dinamakan wakaf adalah perbuatan hukum wakif dengan memberikan harta brnda miliknya untuk diambil manfaatnya yang diperuntukan bagi kepentingan ibadah, sosial maupun untuk kesejahteraan soaial. 


\section{Dasar Hukum Wakaf}

Dalam al-Quran disebutkan beberapa ayat berkaitan dengan wakaf di antaranya adalah ayat 18 surat al-Hadiid yang artinya: "Sesungguhnya orang-orang yang bersedekah baik laki-laki maupun perempuan dan meminjamkan kepada Allah pinjaman yang baik, niscaya akan dilipatgandakan (pembayarannya) kepada mereka, dan bagi mereka pahala yang banyak." (QS. Al-Hadid: 18)

Dalil lain adalah ayat 92 surat Ali Imran yang artinya: "Kamu sekali-kali tidak sampai pada kebajikan (yang sempurna), sebelum kamu menyedekahkan sebagian harta yang kamu cintai. Dan apa saja yang kamu sedekahkan, maka sesungguhnya Allah mengetahuinya." (QS. Ali Imran: 92)

Ayat lain yang menjadi dalil adalah ayat 267 surat alBaqarah yang artinya: "Hai orang-orang yang beriman, sedekahlah (di jalan Allah) sebagian hasil usahamu yang baik-baik dan sebagian dari apa yang kami keluarkan dari bumi untuk kamu. Dan janganlah kamu memilih yang buruk-buruk lalu kamu sedekahkan dari padanya, padahal kamu sendiri tidak mau mengambilnya melainkan dengan memincingkan mata terhadapnya. Dan ketahuilah bahwa Allah Maha Kaya lagi Maha Terpuji." (QS. Al-Baqarah: 267)

Sedangkan hadis Nabi yang menjadi dalil wakaf adalah hadis riwayat Muslim berasal dari Abu Hurairah, bahwa Rasulullah SAW bersabda: "Seorang manusia yang meninggal dunia akan berhenti semua pahala amal perbuatannya, kecuali tiga perkara, yaitu pahala amalan shadaqah jariah yaitu sedekah yang pahalanya tetap mengalir yang diberikannya selama ia hidup, pahala ilmu yang bermanfaat bagi orang lain yang diajarkannya selama hayatnya, dan doa anak saleh." (HR. Muslim)

Selain itu hadis yang menyebutkan Ustman bin Affan membeli sebuah sumur di kota Madinah. Sumur itu beliau wakafkan untuk kepentingan umum, namun beliau sendiri ingin memanfaatkan air sumur itu untuk kepentingan seharihari. Hadist yang berkenaan dengan Ustman ini tidak dijumpai 
kata "Habs" (menahan), tetapi fungsi sumur itu yakni untuk kepentingan orang banyak, jelas pengertian wakaf di situ.

Sedangkan dasar praktik wakaf dinegara Indosesia adalah peraturan Perundang-undangan sebagai berikut:

1. Undang Undang Nomor 41 Tahun 2004 Tentang Wakaf

2. Peraturan Pemerintah Nomor 42 Tahun 2006 Tentang Pelaksanaan Undang-Undang Nomor 41 Tahun 2004 Tentang Wakaf

3. Kompilasi hukum islam Indonesia

4. Peraturan Pemerintah Nomor 28 Tahun 1977 Tentang Perwakafan tanah

\section{Rukun-rukun wakaf}

Dalam hukum Islam, wakaf harus memenuhi unsur-unsur pembentuk yang merupakan rukun wakaf, (Muhammad Daud Ali, 1998: 84) yaitu:

1. Orang yang berwakaf (waqif),

2. Harta yang diwakafkan (mauquf)

3. 3) Tujuan wakaf atau yang berhak menerima hasil wakaf (mauquf'alaihi)

4. Pernyataan wakaf dari wakif yang disebut sighat atau ikrar wakaf.

Sedangkan menurut pasal 6 Undang Undang Nomor 41 Tahun 2004 tentang Wakaf, rukun wakaf meliputi:

1. Wakif (pihak yang mewakafkan harta benda miliknya)

2. Nazhir (pihak yang menerima harta benda wakaf dari Wakif untuk dikelola dan dikembangkan sesuai dengan peruntukannya)

3. Harta Benda Wakaf (harta benda wakaf bisa berupa benda bergerak dan bisa berupa benda tidak bergerak)

4. Ikrar Wakaf (pernyataan kehendak Wakif yang diucapkan secara lisan atau tulisan kepada Nazhir untuk mewakafkan harta benda miliknya)

5. peruntukan harta benda wakaf 
Dalam rangka mencapai tujuan dan fungsi wakaf, harta benda wakaf hanya dapat diperuntukan bagi:

1. sarana dan kegiatan ibadah

2. sarana dan kegiatan pendidikan serta kesehatan

3. bantuan kepada fakir miskin, anak terlantar, yatim piatu, beasiswa

4. kemajuan dan peningkatan ekonomi umat

5. kemajuan kesejahteraan umum lainnya yang tidak bertentangan dengan syariah dan peraturan perundangundangan.

6. jangka waktu wakaf (jangka waktu ini disesuaikan dengan kondisi harta benda yang di wakafkan).

Kalau di dalam hukum Islam, nazhir dan jangka waktu wakaf ridak menjadi rukun, sehingga tanpa nazhir dan jangka waktu pelaksanaan wakaf menjadi syah. Akan tetapi karena dunia semakin berkembang, persoalan wakafpun semakin banyak dan wakaf tidak hanya seedar berdimensi ibadah akan tetapi juga berdimensi social, maka hukum positif di Indonesia menambahkan Nazhir dan jangka waktu wakaf. Nazhir adalah pihak yang menerima harta benda wakaf dari Wakif untuk dikelola dan dikembangkan sesuai dengan peruntukannya.

\section{Harta benda wakaf}

Harta Benda Wakaf adalah harta benda yang memiliki daya tahan lama dan/atau manfaat jangka panjang serta mempunyai nilai ekonomi menurut syariah yang diwakafkan oleh Wakif. Harta benda wakaf hanya dapat diwakafkan apabila dimiliki dan dikuasai oleh Wakif secara sah.

Menurut Undang-undang Nomor 41 tahun 2004 tentang Wakaf, harta benda wakaf terdiri dari:

1) benda tidak bergerak, meliputi:

a) hak atas tanah sesuai dengan ketentuan peraturan perundang-undangan yang berlaku baik yang sudah maupun yang belum terdaftar 
b) bangunan atau bagian bangunan yang berdiri di atas tanah

c) tanaman dan benda lain yang berkaitan dengan tanah

d) hak milik atas satuan rumah susun sesuai dengan ketentuan peraturan perundangundangan yang berlaku

e) benda tidak bergerak lain sesuai dengan ketentuan syariah dan peraturan perundangundangan yang berlaku.

2) benda bergerak, adalah harta benda yang tidak bisa habis karena dikonsumsi, meliputi:

a) uang;

b) logam mulia

c) surat berharga

d) kendaraan

e) hak atas kekayaan intelektual

f) hak sewa

g) benda bergerak lain sesuai dengan ketentuan syariah dan peraturan perundang und ${ }^{1}$ angan yang berlaku.

Sedangkan menurut Peraturan Pemerintah Nomor 42 tahun 2006, harta benda wakaf terbagi menjadi:

1) benda tidak bergerak, meliputi:

a) hak atas tanah sesuai dengan ketentuan Peraturan Perundang-undangan baik yang sudah maupun yang belum terdaftar

b) bangunan atau bagian bangunan yang berdiri di atas tanah

c) tanaman dan benda lain yang berkaitan dengan tanah

d) hak milik atas satuan rumah susun sesuai dengan ketentuan Peraturan Perundang-undangan

e) benda tidak bergerak lain sesuai dengan ketentuan prinsip syariah dan Peraturan Perundang-undangan. 
2) benda bergerak selain uang

Benda digolongkan sebagai benda bergerak karena sifatnya yang dapat berpindah atau dipindahkan atau karena ketetapan undang-undang. Benda bergerak terbagi dalam benda bergerak yang dapat dihabiskan dan yang tidak dapat dihabiskan karena pemakaian. Benda bergerak yang dapat dihabiskan karena pemakaian tidak dapat diwakalkan, kecuali air dan bahan bakar minyak yang persediaannya berkelanjutan. Benda bergerak yang tidak dapat dihabiskan karena pemakaian dapat diwakafkan dengan memperhatikan ketentuan prinsip syariah.

Benda bergerak karena sifatnya yang dapat diwakafkan meliputi:

a) kapal;

b) pesawat terbang;

c) kendaraan bermotor;

d) mesin atau peralatan industri yang tidak tertancap pada bangunan;

e) logam dan batu mulia; dan/atau

f) benda lainnya yang tergolong sebagai benda bergerak karena sifatnya dan memiliki manfaat jangka panjang.

Benda bergerak selain uang karena Peraturan Perundangundangan yang dapat diwakafkan sepanjang tidak bertentangan dengan prinsip syariah sebagai berikut:

a. surat berharga yang berupa:

1) saham

2) Surat Utang Negara

3) obligasi pada umumnya

4) surat berharga lainnya yang dapat dinilai dengan uang

b. Hak Atas Kekayaan Intelektual yang berupa: 
1) hak cipta

2) hak merk

3) hak paten

4) hak desain industri

5) hak rahasia dagang

6) hak sirkuit terpadu

7) hak perlindungan varietas tanaman

8) hak Iainnya.

c. hak atas benda bergerak lainnya yang berupa:

9) hak sewa, hak pakai dan hak pakai hasil atas benda bergerak; atau

10) perikatan, tuntutan atas jumlah uang yang dapat ditagih atas benda bergerak.

11) benda bergerak berupa uang.

Wakaf uang yang dapat diwakafkan adalah mata uang rupiah. Jika uang yang akan diwakafkan masih dalam mata uang asing, maka harus dikonversi terlebih dahulu ke dalam rupiah.

\section{Wakaf Uang}

\section{Pengertian wakaf uang}

Menurut fatwa MUI tentang Wakaf Uang, yang dinamakan Wakaf Uang (Cash Wakaf/Waqf al-Nuqud) adalah wakaf yang dilakukan seseorang, kelompok orang, lembaga atau badan hukum dalam bentuk uang tunai. Termasuk ke dalam pengertian uang adalah surat-surat berharga.

Wakaf harta benda bergerak berupa uang yang selanjutnya disebut wakaf uang adalah wakaf berupa uang yang dapat dikelola secara produktif, hasilnya dimanfaatkan untuk Mauquf alaih. (Peraturan BWI nomor 1 tahun 2009 tentang Pedoman Pengelolaan dan Pengembangan Harta Benda Wakaf Bergerak Berupa Uang).

Di dalam Undang-Undang Nomor 41 tahun 2004 tentang Wakaf Pasal 28-31 dan Peraturan Pemerintah Nomor 42 tahun 
2006 tentang Pelaksanaan Undang-Undang Nomor 41 Tahun 2004 tentang Wakaf, Pasal 22-27 telah mengatur bolehnya pelaksanaan wakaf uang (harta benda berupa uang).

Dengan demikian yang dimaksud wakaf uang adalah wakaf yang dilakukan oleh wakif (perseorangan, kelompok orang dan lembaga atau badan hukum dalam bentuk uang dan suratsurat berharga, seperti saham, cek dan lainnya.

\section{Dasar hukum wakaf uang}

Al-Quran Surat Al-Hadiid ayat 18 yang artinya: "Sesungguhnya orang-orang yang bersedekah baik laki-laki maupun perempuan dan meminjamkan kepada Allah pinjaman yang baik, niscaya akan dilipatgandakan (pembayarannya) kepada mereka, dan bagi mereka pahala yang banyak." (QS. Al-Hadid: 18)

Surat Ali Imran ayat 92 yang artinya: "Kamu sekali-kali tidak sampai pada kebajikan (yang sempurna), sebelum kamu menyedekahkan sebagian harta yang kamu cintai. Dan apa saja yang kamu sedekahkan, maka sesungguhnya Allah mengetahuinya." (QS. Ali Imran: 92)

Surat Al-Baqarah ayat 267 yang artinya: "Hai orang-orang yang beriman, sedekahlah (di jalan Allah) sebagian hasil usahamu yang baik-baik dan sebagian dari apa yang kami keluarkan dari bumi untuk kamu. Dan janganlah kamu memilih yang buruk-buruk lalu kamu sedekahkan dari padanya, padahal kamu sendiri tidak mau mengambilnya melainkan dengan memincingkan mata terhadapnya. Dan ketahuilah bahwa Allah Maha Kaya lagi Maha Terpuji." (QS. Al-Baqarah: 267)

Sedangkan hadis yang menjadi dalil adalah hadis riwayat Muslim berasal dari Abu Hurairah, bahwa Rasulullah SAW bersabda: "Seorang manusia yang meninggal dunia akan berhenti semua pahala amal perbuatannya, kecuali tiga perkara, yaitu pahala amalan shadaqah jariah yaitu sedekah yang pahalanya tetap mengalir yang diberikannya selama ia hidup, pahala ilmu yang bermanfaat bagi orang lain yang diajarkannya selama hayatnya, dan doa anak saleh." (HR. Muslim) 
Hadis Riwayat Bukhari Muslim, yang menceritakan bahwa pada suatu hari sahabat Umar datang pada Nabi Muhammad SAW untuk minta nasehat entang tanah yang diperolehnya di Khaibar (daerah yang amat subur di Madinah), lalu is berkata; Ya Rasulullah, apakah yang engkau perintahkan kepadaku rnengenai tanah itu ? Lalu Rasulullah berkata: Kalau engkau mau, dapat engkau tahan asalnya (pokoknya) dan engkau bersedekah dengan dia, maka bersedekahlah Umar dengan tanah itu, dengan syarat pokoknya tiada dijual, tiada dihibahkan dan tiada pula diwariskan.

Sedangkan dasar wakaf uang di Indonesia yang berupa Peraturan Perundang-undangan adalah:

1) Fatwa MUI tahun 2002 tentang Wakaf Uang

2) Undang Undang Nomor 41 Tahun 2004 Tentang Wakaf

3) Peraturan Pemerintah Nomor 42 Tahun 2006 Tentang Pelaksanaan Undang-Undang Nomor 41 Tahun 2004 Tentang Wakaf

4) Peraturan Menteri agama nomor 4 tahun 2009 tentang Administrasi Wakaf Uang

5) Keputusan Menteri agama nomor 92-96 rentang Penetapan 5 LKS menjadi LKS PWU

6) Peraturan BWI nomor 1 tahun 2009 Pedoman Pengelolaan dan Pengembangan Harta Benda Wakaf Bergerak Berupa Uang

\section{Jenis wakaf uang}

Dari jangka waktunya, wakaf uang bisa dibagi menjadi:

1) Wakaf uang dengan jangka waktu tertentu

2) Wakaf uang dengan jangka waktu selamanya (Forum Lembaga Keuangan Syariah Penerima Wajaf Uang, 2013: 10).

Perbedaan ke dua jenis wakaf uang tersebut di atas dapat dilihat dari tabel berikut ini: 


\begin{tabular}{rlll}
\hline No & Perbedaan & $\begin{array}{l}\text { Wakaf uang jangka } \\
\text { waktu tertentu }\end{array}$ & $\begin{array}{l}\text { Wakaf uang jangka } \\
\text { waktu selamanya }\end{array}$ \\
\hline 1 & Nominal wakaf & Minimal Rp 10 juta & Tidak ada batasan \\
\hline 2 & Jangka waktu & Minimal 5 tahun & Selamanya \\
\hline 3 & Investasi & $\begin{array}{l}\text { Produk LKS PWU di } \\
\text { tempat sector wakaf }\end{array}$ & Produk syariah \\
\hline 4 & Pokok wakaf & $\begin{array}{l}\text { Bisa kembali ke } \\
\text { Wakif }\end{array}$ & $\begin{array}{l}\text { Tidak bisa kembali } \\
\text { ke Wakif }\end{array}$ \\
\hline
\end{tabular}

\section{Pihak-pihak yang terlibat dalam wakaf uang}

Dalam pelaksanaan wakaf uang, ada pihak-pihak yang terlibat di dalam wakaf uang ini, yaitu:

1) Wakif, yakni orang, lembaga maupun badan hukum yang mau mewakafkan uangnya

2) Nazhir, pihak yang menerima harta benda wakaf dari Wakif untuk dikelola dan dikembangkan sesuai dengan peruntukannya.

3) LKS-PWU, adalah badan hukum Indonesia yang bergerak di bidang keuangan Syariah.

4) PPAIW, Pejabat Lembaga Keuangan Syariah paling rendah setingkat Kepala Seksi LKS yang ditunjuk oleh Menteri

\section{Tata cara dan pengelolaan wakaf uang di Indonesia}

Wakaf uang merupakan bentuk wakaf yang sangat mudah untuk dilakukan dan tentunya sangat bermanfaat bagi umat. Kemudahannya hanya menyerahkan sejumlah uang dan pemanfaatan wakaf uang ini bisa untuk kesejahteraan masyarakat.

Wakif dapat mewakafkan benda bergerak berupa uang melalui lembaga keuangan syariah yang ditunjuk oleh Menteri. Wakaf benda bergerak berupa uang dilaksanakan oleh Wakif dengan pernyataan kehendak Wakif yang dilakukan secara tertulis. Wakaf benda bergerak berupa uang diterbitkan dalam bentuk sertifikat wakaf uang. Sertifikat wakaf uang diterbitkan 
dan disampaikan oleh lembaga keuangan syariah kepada Wakif dan Nazhir sebagai bukti penyerahan harta benda wakaf.

Lembaga keuangan syariah atas nama Nazhir mendaftarkan harta benda wakaf berupa uang kepada Menteri selambat-lambatnya 7 (tujuh) hari kerja sejak diterbitkannya Sertifikat Wakaf Uang.

Wakaf uang yang dapat diwakafkan adalah mata uang rupiah. Dalam hal uang yang kan diwakafkan masih dalam mata uang asing, maka harus dikonversi terlebih dahulu ke dalam rupiah (Peraturan BWI Nomor 1 tahun 2009 tentang Pedoman Pengelolaan dan Pengembangan Harta Benda Wakaf Bergerak Berupa Uang). Wakif yang akan mewakafkan uangnya diwajibkan untuk:

a) hadir di Lembaga Keuangan Syariah Penerima Wakaf Uang (LKS-PWU) untuk menyatakan kehendak wakaf uangnya;

b) menjelaskan kepemilikan dan asal-usul uang yang akan diwakafkan;

c) menyetorkan secara tunai sejumlah uang ke LKS PWU

d) mengisi formulir pernyataan kehendak Wakif yang berfungsi sebagai AIW (Peraturan Pemerintah Nomor 42 Tahun 2006 Tentang Pelaksanaa Undang Undang Nomor 41 Tahun 2004 Tentang wakaf)

Apabila Wakif tidak dapat hadir, maka Wakif dapat menunjuk wakil atau kuasanya untuk hadir dalam penterahan wakaf uang. Wakif atau wakil atau kuasanya dapat menyatakan ikrar wakaf benda bergerak berupa uang kepada Nazhir di hadapan Pejabat Pembuat Akta Ikrar Wakaf (PPAIW) yang selanjutnya Nazhir menyerahkan Akta Ikrar Wakaf (AIW) tersebut kepada LKS-PWU.

Wakif dapat mewakafkan uang melalui LKS yang ditunjuk oleh Menteri sebagai LKS Penerima Wakaf Uang (LKS-PWU). LKS yang ditunjuk oleh Menteri atas dasar saran dan pertimbangan dari BWI. BWI memberikan saran dan 
pertimbangan setelah mempertimbangkan saran instansi terkait. Saran dan pertimbangan dapat diberikan kepada LKS-PWU yang memenuhi persyaratan sebagai berikut:

a) menyampaikan permohonan secara tertulis kepada Menteri;

b) melampirkan anggaran dasar dan pengesahan sebagai badan hukum;

c) memiliki kantor operasional di wilayah Republik Indonesia;

d) bergerak di bidang keuangan syariah; dan

e) memiliki fungsi menerima titipan (wadiah).

Lembaga Keuangan Syariah Penerima Wakaf Uang (LKSPWU) bertugas:

a) mengumumkan kepada publik atas keberadaannya sebagai LKS Penerima Wakaf Uang

b) menyediakan blangko Sertifikat Wakaf Uang

c) menerima secara tunai wakaf uang dari Wakif atas nama Nazhir

d) menempatkan uang wakaf ke dalam rekening titipan (wadiah) atas nama Nazhir yang ditunjuk Wakif

e) menerima pernyataan kehendak Wakif yang dituangkan secara tertulis dalam formulir pernyataan kehendak Wakif;

f) menerbitkan Sertifikat Wakaf Uang serta menyerahkan sertifikat tersebut kepada Wakif dan menyerahkan tembusan sertifikat kepada Nazhir yang ditunjuk oleh Wakif

g) mendaftarkan wakaf uang kepada Menteri atas nama Nazhir. (Peraturan Pemerintah Nomor 42 Tahun 2006 Tentang Pelaksanaa Undang Undang Nomor 41 Tahun 2004 Tentang wakaf)

Sertifikat wakaf uang sekurang-kurangnya memuat keterangan mengenai:

a) nama LKS Penerima Wakaf Uang; 


\section{Junaidi Abdullah}

b) nama Wakif;

c) alamat Wakif;

d) jumlah wakaf uang;

e) peruntukan wakaf;

f) jangka waktu wakaf;

g) nama Nazhir yang dipilih;

h) alamat Nazhir yang dipilih; dan

i) tempat dan tanggal penerbitan Sertifikat Wakaf Uang.

Dalam hal Wakif berkehendak melakukan perbuatan hukum wakaf hang untuk jangka waktu tertentu maka pada saat jangka waktu tersebut berakhir, Nazhir wajib mengembalikan jumlah pokok wakaf uang kepada Wakif atau ahli waris/penerus haknya melalui LKS PWU.

Wakaf uang, investasi wakaf uang dan hasil invertasi wakaf uang yang telah disetorkan dari wakif melalui LKS PWU, selanjutnya akan dikelola oleh Nazhir. Pengelolaan dan pengembangan wakaf uang oleh Nazhir melalui dua mekanisme:

1. Pengelolaan dan pengembangan wakaf uang atas setoran wakaf uang dan investasi wakaf uang oleh Nazhir wajib ditujukan untuk optimalisasi perolehan keuntungan dan/ atau pemberdayaan ekonomi ummat.

2. Pengelolaan dan pengembangan wakaf uang atas hasil investasi wakaf uang oleh Nazhir wajib ditujukan untuk pemberdayaan ekonomi ummat dan/atau kegiatankegiatan social keagamaan (Peraturan BWI nomor 1 tahun 2009 tentang Pedoman Pengelolaan dan Pengembangan Harta Benda Wakaf Bergerak Berupa Uang).

Nazhir sebagai pengelolai wakaf uang, ditetapkan paling banyak sebagai berikut:

a. $10 \%$ (sepuluh perseratus), apabila besarnya investasi wakaf uang paling kurang mencapai 90\% (sembilan puluh perseratus) dibanding setoran wakaf uang 
b. $9 \%$ (sembilan perseratus), apabila besarnya investasi wakaf uang paling kurang mencapai 70\% (tujuh puluh perseratus) dibanding setoran wakaf uang;

c. $8 \%$ (delapan perseratus), apabila besarnya investasi wakaf uang paling kurang mencapai 50\% (lima puluh perseratus) dibanding setoran wakaf uang;

d. 5\% (lima perseratus), apabila besarnya investasi wakaf uang dibawah 50\% (lima puluh perseratus) dibanding setoran wakaf uang. (Peraturan BWI nomor 1 tahun 2009 tentang Pedoman Pengelolaan dan Pengembangan Harta Benda Wakaf Bergerak Berupa Uang).

\section{Simpulan}

Dari pembahasan di atas, maka dapat disimpulkan sebagai berikut:

1. Bahwa tata cara wakaf uang adalah Wakif yang akan mewakafkan uangnya diwajibkan untuk:

a. hadir di Lembaga Keuangan Syariah Penerima Wakaf Uang (LKS-PWU) untuk menyatakan kehendak wakaf uangnya;

b. menjelaskan kepemilikan dan asal-usul uang yang akan diwakafkan;

c. menyetorkan secara tunai sejumlah uang ke LKS PWU

d. mengisi formulir pernyataan kehendak Wakif yang berfungsi sebagai AIW

2. Pengelolaan Wakaf uang oleh Nazhir melalui:

a. Pengelolaan dan pengembangan wakaf uang atas setoran wakaf uang dan investasi wakaf uang oleh Nazhir wajib ditujukan untuk optimalisasi perolehan keuntungan dan/ atau pemberdayaan ekonomi ummat.

b. Pengelolaan dan pengembangan wakaf uang atas hasil investasi wakaf uang oleh Nazhir wajib ditujukan untuk pemberdayaan ekonomi ummat dan/atau kegiatankegiatan social keagamaan (Peraturan BWI nomor 1 tahun 
2009 tentang Pedoman Pengelolaan dan Pengembangan Harta Benda Wakaf Bergerak Berupa Uang).

\section{Daftar Pustaka}

Ensiklopedi Hukum Islam, PT. Ichfiar Baru Van Hoeve, Jakarta, 1997.

Fatwa MUI tentang Wakaf Uang

Forum Lembaga Keuangan Syariah Penerima Wajaf Uang, Handbook Tanta Jawab Wakaf Uang, BWI, Jakarta, 2013.

Kompilasi Hukum Islam Indonesia

Muhammad Daud Ali, Sistem Ekonomi Islam, Zakat dan Wakaf, UI Press, Jakarta, 1988.

Peraturan BWI Nomor 1 tahun 2009 tentang Pedoman Pengelolaan dan Pengembangan Harta Benda Wakaf Bergerak Berupa Uang

Peraturan Pemerintah Nomor 28 Tahun 1977 Tentang Perwakafan Tanah

Peraturan Pemerintah Nomor 42 Tahun 2006 Tentang Pelaksanaa Undang Undang Nomor 41 Tahun 2004 Tentang Wakaf

Said Agil Husin Al-Munawar, Hukum Islam dan Pluralitas Sosial, Penamadani, Jakarta, 2004.

Siah Khosyi'ah, Wakaf Dan Hibah; Perseptif Ulama Figh Dan Perkembangannya Di Indonesia, Pustaka Setia, Bandung, 2010.

Undang Undang Nomor 41 Tahun 2004 Tentang Wakaf 